\title{
In vitro cytotoxic, antioxidant and antiviral effects of Pterocaulon alopecuroides and Bidens segetum extracts
}

\author{
Cristiane Silva Silveira, ${ }^{1}$ Fernanda Otaviano Martins, ${ }^{2}$ Clarice dos Santos Costa, ${ }^{1}$ Maria \\ Teresa Villela Romanos, ${ }^{2}$ Maria Auxiliadora Coelho Kaplan, ${ }^{1}$ Fábio de Sousa Menezes *,3 \\ ${ }^{1}$ Núcleo de Pesquisa em Produtos Naturais, Centro de Ciências da Saúde, Universidade Federal do 21941-590 \\ Rio de Janeiro-RJ, Brazil, \\ ${ }^{2}$ Laboratório Experimental de Drogas Antivirais e Citotóxicas, Departamento de Virologia, Instituto de \\ Microbiologia Prof. Paulo de Góes, Universidade Federal do Rio de Janeiro, \\ 21941-590 Rio de Janeiro- RJ, Brazil, \\ ${ }^{3}$ School of Pharmacy and Pharmaceutical Sciences, Trinity College Dublin, University of Dublin, Dublin 2, \\ Ireland
}

\begin{abstract}
RESUMO: "Efeitos citotóxico, antioxidante e antiviral in vitro de extratos de Pterocaulon alopecuroides e Bidens segetum". Pterocaulon alopecuroides (Lamark) De Candolle e Bidens segetum Mart. ex Colla são duas espécies pertencentes à família Asteraceae. Os extratos dessas duas espécies foram avaliados quanto às suas atividades citotóxica, antioxidante e antiviral. Todos os extratos analisados apresentaram citotoxidade muito alta contra linhagens de células RBL-2H3. O ensaio de atividade antioxidante demonstrou uma alta atividade das frações em acetato de etila de $B$. segetum e $P$. alopecuroides. Isso pode ser parcialmente explicado pelo alto conteúdo de cumarinas, ao menos para $P$. alopecuroides. Nenhum dos extratos etanólicos totais de $B$. segetum mostraram atividade significativa contra o vírus Herpes simplex (Tipos 1 e 2 resistentes ao aciclovir). $\mathrm{O}$ extrato etanólico de $P$. alopecuroides também foi inativo contra o vírus Herpes simplex tipo 1 resistente ao aciclovir. Entretanto, este extrato apresentou atividade inibitória contra o vírus Herpes simplex tipo 2 resistente ao aciclovir. Do extrato etanólico bruto de $P$. alopecuroides foi possível isolar a 7-(2',3'-dihidroxi-3'-metilbutiloxi)-6-metoxicumarina, a qual foi testada nas mesmas condições, demonstrando um índice de inibição viral quase duas vezes maior do que o da amostra de $P$. alopecuroides para HSV-2-ACVr. A cumarina tabém foi ativa contra HSV-1-ACVr. Esses resultados evidenciam a importância de Pterocaulon alopecuroides e Bidens segetum como plantas medicinais.
\end{abstract}

Unitermos: Pterocaulon alopecuroides, Bidens segetum, atividade antiviral, atividade citotóxica, atividade antioxidante, 7-(2',3'-dihidroxi-3'-metilbutiloxi)-6-metoxicumarina.

\begin{abstract}
Pterocaulon alopecuroides (Lamark) De Candolle and Bidens segetum Mart. ex Colla are two species belonging to the Asteraceae family. Extracts from those two species were evaluated to their cytotoxic, antioxidant and antiviral activities. All the extracts assayed have shown a very high cytotoxity against RBL-2H3 cell line. The antioxidant assay pointed out a really high activity of the ethyl acetate extracts for $B$. segetum and $P$. alopecuroides. This can be partially explained due to the high content of coumarins, at least for $P$. alopecuroides. None of the total ethanol extracts from $B$. segetum showed significant activity against the two strains of Herpes simplex virus (Types 1 and 2 resistant to acyclovir). P. alopecuroides ethanol extract was also inactive against the Herpes simplex virus type 1 resistant to acyclovir. However, this extract presented inhibitory activity against the Herpes simplex virus type 2 resistant to acyclovir. From the ethanol crude extract of $P$. alopecuroides, it was possible to isolate 7-(2',3'-dihidroxy-3'methylbutyloxy)-6-methoxycoumarin, which was tested in the same conditions, showing a viral inhibitory rate almost twice bigger than the $P$. alopecuroides sample for HSV-2-ACVr. The coumarin was also active against HSV-1-ACVr. Those results provide further evidence of the importance of Pterocaulon alopecuroides and Bidens segetum as medicinal plants.
\end{abstract}

Keywords: Pterocaulon alopecuroides, Bidens segetum, antiviral activity, cytotoxic activity, antioxidant activity, 7-(2',3'-dihidroxy-3'-methylbutyloxy)-6-methoxycoumarin.

\section{INTRODUCTION}

Pterocaulon alopecuroides (Lamark) De Candolle and Bidens segetum Mart. ex Colla are two species belonging to the Asteraceae family, one of the biggest families of Angiospermae (Da Costa et al., 2005). Species from Bidens genus occurs in tropical regions (Ballard, 1986; Agra et al., 2007 and 2008) 
and they are rich in quercetin (Hoffmann, 1989; Lastra Valdes, 2001) and other polyphenolic compounds (Rice-Evans, 1996). It has been reported antibacterial (Rabe and Van Staden, 1997), antimalarial (Oliveira et al., 2004), antioxidant and immunomodulatory effects for Bidens species (Abajo et al., 2004). P. alopecuroides is widely distributed in North and South America and Australia. Twelve species belonging to Pterocaulon genus have previously been mentioned as medicinal (Maes et al., 2006). Studies concerning pharmacological activities report antiviral activity against poliovirus and rhinovirus (Semple et al., 1998, 1999), antibacterial activity (Macleod and Rasmussen, 1999), DNA interaction and anti-tumor activities (Mongelli et al., 2000), anti-proliferative and differentiating properties on human leukemia cells (Riveiro et al., 2004) and antifungal activity (Stein et al., 2005). The main class of active coumponds found in Pterocaulon genus are terpenes, flavonoids and coumarins (Bohlmann et al., 1981; Debenedetti et al., 1997, 1999; Macleod and Rasmussen, 1999; Riveiro et al., 2004; Semple et al., 1999; Vera et al., 2001; Vilegas et al., 1995).

This work was undertaken to evaluate the in vitro antioxidant, cytotoxic and antiviral activities of Pterocaulon alopecuroides and Bidens segetum extracts, altogether with a coumarin isolated from $P$. alopecuroides ethanol extract.

\section{MATERIAL AND METHODS}

\section{Plant material}

Pterocaulon alopecuroides and Bidens segetum aerial parts were collected on april 2005, in Nova Friburgo, State of Rio de Janeiro, Brazil. The GPS coordinates were $22^{\circ} 23^{\prime} 17.2^{\prime \prime} \mathrm{S}$ and $42^{\circ} 17^{\prime} 23.0^{\prime \prime}$ $\mathrm{W}$ for $P$. alopecuroides and $22^{\circ} 23^{\prime} 19.7^{\prime \prime} \mathrm{S}$ and $42^{\circ}$ 17 ' 18.6" W for B. segetum. The plant material was identified by Dr. Rosana C. Lopes (Department of Botany, CCS, Federal Universidade Federal do Rio de Janeiro). Voucher specimens were deposited in the Herbarium of the Botany Department - RFA.

\section{Extract preparations}

Bidens segetum was separated in flowers and leaves/stems, while for Pterocaulon alopecuroides, aerial parts were employed. Dried plant materials were powdered and submitted to exhaustive extraction with ethanol at room temperature. The obtained extracts were concentrated under reduced pressure. The residue was suspended in water and submitted to a sequential liquidliquid extraction with the following different solvents: hexane, dichloromethane, ethyl acetate and $n$-butanol, providing new extracts as in Matheus et al., 2005.

Isolation and identification of compounds
The ethanol extract from Pterocaulon alopecuroides $(2.55 \mathrm{~g}$ ) was chromatographed by High Speed Counter-Current Chromatography (HSCCC) using $\mathrm{C}_{6} \mathrm{H}_{6}-$ EtOAc-MeOH- $\mathrm{H}_{2} \mathrm{O}(4: 5: 3: 1.3)$ as solvent system. The upper phase was used as mobile phase. The flow rate was $2 \mathrm{ml} / \mathrm{min}$ and the rotation speed was $850 \mathrm{rpm}$. The fraction volume was $4 \mathrm{~m} \ell$ and a total of 109 fractions were obtained. The fractions were joined, followed by TLC using silica gel, and the fractions 78-87 were re-chromatographed in Sephadex LH-20® column eluted with $\mathrm{MeOH}$. A total of 73 fractions were obtained and $90.5 \mathrm{mg}$ of the 7-(2',3'-dihidroxy3'-methylbutyloxy)-6-methoxycoumarin was isolated from fractions 13-17. The coumarin was identified based on its spectral data $\left({ }^{1} \mathrm{H}\right.$ NMR $600 \mathrm{MHz},{ }^{13} \mathrm{C}$ NMR $150 \mathrm{MHz})$.

\section{Cytotoxicity assay}

The assay was performed with a cytotoxicity detection kit designed as a precise, fast and simple colorimetric alternative to quantify cytotoxicity based on the measurement of lactate dehydrogenase (LDH) activity released from damaged cells (RBL-2H3).

A sterile 96-wells tissue culture plate was filled according to Table 1, in triplicate wells for each control and sample. Plate was incubated at $37^{\circ} \mathrm{C}$ for 24 hours, in atmosphere of $5 \% \mathrm{CO}_{2}$ and $90 \%$ humidity. Cells were removed from microplate by centrifuging them at $250 \mathrm{x}$ g for 10 minutes and $100 \mu \ell /$ well supernatant was carefully transferred into corresponding wells of an optically clear 96-wells flat bottom microplate. To determine the LDH activity in these supernatants, 100 $\mu \mathrm{L}$ of reaction mixture was added to each well and incubate for up to 30 minutes at $25^{\circ} \mathrm{C}$, protected from light. The absorbance of the samples was measured at 490nm using a microplate analyser Fusion Universal (Packard BioScience Co.).

To determine the percentage cytotoxicity $(\mathrm{C} \%)$, the average absorbance values (ABS) of the triplicates were calculated. The resulting values are substituted in the following equation:

$$
\begin{aligned}
& \mathrm{C} \%=\left\{\left[\left(\mathrm{ABS}_{\text {SAMPLE }}-\mathrm{ABS}_{\text {BACKGROUND CONTROL }}\right)-\mathrm{ABS}_{\text {LOW }}\right.\right. \\
& \text { CONTroL } \left.] \text { / }\left(\mathrm{ABS}_{\text {HIGH CONTROL }}-\mathrm{ABS}_{\text {LOW CONTROL }}\right)\right\} \times 100
\end{aligned}
$$

\section{Antioxidant assay}

This assay was performed by 2,2-diphenyl1-picrilhydrazil (DPPH) stable free radical photocolorimetric method, according previously published papers (Menezes et al., 2005; Silva et al., 2005; Falcão et al., 2006; Vicentino and Menezes, 2007; Nunes et al., 2008). The ethanol extracts of Bidens segetum flowers, Bidens segetum leaves/stems, Pterocaulon alopecuroides aerial parts and their partition extracts in dichloromethane, ethyl acetate and 
$n$-butanol were evaluated. Results were compared to Ginkgo biloba standard, EGb 761®, which is known by its free radical scavenging property.

\section{Antiviral assay}

Extracts and pure compound were lyophilized and solved in water to a final concentration of $400 \mu \mathrm{g} /$ $\mathrm{m} \ell$. Each solution was sterilized by filtration using a $0.22 \mu \mathrm{m}$ Milipore membrane, aliquoted and stored at $20{ }^{\circ} \mathrm{C}$.

In order to evaluate the antiviral activity, the extracts were assayed at the maximum non-toxic concentrations (MNTC), which is unable to produce any morphological alterations on the cells tested. Vero cells (African green monkey's kidney) were grown in Eagle's minimum essential medium (MEM) supplemented with $10 \%$ of fetal bovine serum (FBS) and maintained at $37{ }^{\circ} \mathrm{C}$ in atmosphere of $5 \% \mathrm{CO}_{2}$. Antiviral activity was determined by reduction of the virus titres. Logarithmical dilutions of virus suspension were added to the treated and untreated cell cultures and incubated at $37{ }^{\circ} \mathrm{C}$ in atmosphere of $5 \% \mathrm{CO}_{2}$. After that, the virus titres determination was performed using Reed and Muench (1938) statistical method and expressed as $\mathrm{TCID}_{50}$ values. The results were expressed as percentage of inhibition (PI) and viral inhibition index (VII) according with described for Gonçalves et al. (2001).

\section{RESULTS AND DISCUSSION}

All the three extracts evaluated at the cytotoxicity assay have shown a very high cytotoxicity power against RBL-2H3 cells (Table 1). The extract of flowers of $B$. segetum and the extract of $P$. alopecuroides were almost as active as Triton $\mathrm{X}$ (high control) and about $30 \%$ higher than the terfenadine standard (positive control). These results offer evidence that $B$. segetum and $P$. alopecuroides extracts may have an important role in cancer treatment studies and the partition extracts of these two species must be evaluated as well.

Cancer is one of a series of diseases that can be originated by oxidative damage (Castro and Freeman, 2001). Compounds with scavenging properties have been studied in several chronic diseases caused by free radicals (Matheus et al., 2006). Very few systematic studies have been reported on structure-antioxidant activity correlations in coumarins, but their activity is probably due to their structural analogy with flavonoids and benzophenones (Farombi and Nwaokeafor 2005). In fact, as substitutions can occur at any of the six available sites of their basic molecular moiety (1,2-benzopyrone), coumarins possess a great structural diversity (Beillerot et al., 2008).

The antioxidant assay performed here pointed out a really high activity of the ethyl acetate extracts of B. segetum and P. alopecuroides (Table 2). This can occur due to the high content of coumarins of these extracts. Only the dichloromethane extract of $P$. alopecuroides, the dichloromethane extract of $B$. segetum leaves/stems, the ethanol extract of $B$. segetum flowers and its partition in $n$-butanol presented a higher $\mathrm{CE}_{50}$ than the Ginkgo biloba standard (Table 2).

Coumarins are a group of natural compounds which are extremely variable in structure (Beillerot et al., 2008), leading to compounds displaying multiple biological properties as in vitro antiproliferative and in vivo antitumor activities (Kostova, 2005); antioxidant activity (Beillerot et al., 2008; Farombi and Nwaokeafor, 2005; Fylaktakidou et al., 2004; Girennavar et al., 2007; Kontogiorgis et al., 2004; Torres et al., 2006; Wua et al., 2007; von Kruedener et al., 1996); inhibitory activity against cytochrome P450 enzyme (Girennavar et al., 2007); neuroprotective, anticancer and antimutagenic activities (Borges et al., 2005; Stanczyk et al., 2005); anti-inflammatory activity (Borges et al., 2005; Khan and Sharma, 1993; Kontogiorgis et al., 2004; Stanczyk et al., 2005); vasorelaxant (Hoult and Paya, 1996) and anticoagulant activities (Khan and Sharma, 1993). Some studies reveal that the multiple pharmacological activities of coumarins may be related to their antioxidant properties (Borges et al., 2005; Stanczyk et al., 2005), as oxidative damage to biomolecules causes accelerated aging and many chronic diseases, including neurodegenerative diseases, cancer, cardiovascular

Table 1. Percentage of cytotoxic effect (CE) for Pterocaulon alopecuroides and Bidens segetum ethanol extracts.

\begin{tabular}{|c|c|c|c|c|c|}
\hline Contents of the well & Background Control & Low Control & High Control & $\begin{array}{c}\text { Samples }(200 \\
\mu \mathrm{L} \text { each })\end{array}$ & $\mathrm{CE}(\%)$ \\
\hline Assay medium DMEM + 1\% (w/v) BSA & $200 \mu \mathrm{L}$ & $100 \mu \mathrm{L}$ & --------- & -------- & $\begin{array}{ll}------ \\
--1\end{array}$ \\
\hline Mastocytes Cells NRL-2H3 & --------- & $100 \mu \mathrm{L}$ & $100 \mu \mathrm{L}$ & $100 \mu \mathrm{L}$ & 0 \\
\hline Triton- $X$ Solution ( $2 \%$ in assay medium) & --------- & --------- & $100 \mu \mathrm{L}$ & --------- & 100 \\
\hline $\begin{array}{l}\text { Ethanol extract of } P \text {. alopecuroides }(100 \\
\mu \mathrm{g} / \mathrm{m} \ell \text { in DMSO) }\end{array}$ & --------- & --------- & --- & $100 \mu \mathrm{L}$ & 96.26 \\
\hline $\begin{array}{l}\text { Ethanol extract of flowers of } B . \text { segetum } \\
(100 \mu \mathrm{g} / \mathrm{m} \ell \text { in DMSO })\end{array}$ & --------- & --------- & --------- & $100 \mu \mathrm{L}$ & 98.79 \\
\hline $\begin{array}{l}\text { Ethanol extract of leaves/stems of } B \text {. } \\
\text { segetum }(100 \mu \mathrm{g} / \mathrm{m} \ell \text { in DMSO })\end{array}$ & - & --------- & --------- & $100 \mu \mathrm{L}$ & 90.16 \\
\hline Terfenadine Standard $100 \mathrm{mM}$ in DMSO & --------- & -------- & --------- & $100 \mu \mathrm{L}$ & 66.43 \\
\hline
\end{tabular}


Table 2. Antioxidant activity percentage and CE50 of B. segetum flowers ethanol extract (BSFEE) and its partitions extracts in $n$-butanol (BSFBE), ethyl acetate (BSFEAE) and dichlorometane (BSFDE); of $B$. segetum leaves/stems ethanol extract (BSLSEE) and its partitions extracts in $n$-butanol (BSLSBE), ethyl acetate (BSLSEAE) and dichlorometane (BSLSDE); and of $P$. alopecuroides ethanol extract (PAEE) and its partitions extracts in $n$-butanol (PABE), ethyl acetate (PAEAE) and dichlorometane (PADE); comparing with standard of Ginkgo biloba EGb 761®.

\begin{tabular}{|c|c|c|c|c|c|c|c|}
\hline \multicolumn{7}{|c|}{ Antioxidant activity $(\%) \pm$ Standard error } & \multirow[b]{2}{*}{$\begin{array}{r}\text { CE50 } \\
\mu \mathrm{g} / \mathrm{mL}\end{array}$} \\
\hline Samples & $\begin{array}{c}5 \\
\mu \mathrm{g} / \mathrm{mL} \\
\end{array}$ & $\begin{array}{c}10 \\
\mu \mathrm{g} / \mathrm{mL}\end{array}$ & $\begin{array}{c}25 \\
\mu \mathrm{g} / \mathrm{mL} \\
\end{array}$ & $\begin{array}{c}50 \\
\mu \mathrm{g} / \mathrm{mL} \\
\end{array}$ & $\begin{array}{c}125 \\
\mu \mathrm{g} / \mathrm{mL}\end{array}$ & $\begin{array}{c}250 \\
\mu \mathrm{g} / \mathrm{mL}\end{array}$ & \\
\hline BSFEE & $4.04+0.59$ & $8.32 \pm 1.38$ & $18.13 \pm 2.55$ & $28.58 \pm 2.73$ & $68.25 \pm 1.36$ & $91.51 \pm 0.49$ & 84.97 \\
\hline BSFBE & $2.19 \pm 0.85$ & $10.36 \pm 0.50$ & $25.31 \pm 0.59$ & $54.40 \pm 0.72$ & $90.30 \pm 0.36$ & $93.68 \pm 0.46$ & 51.72 \\
\hline BSFEAE & $28.48 \pm 0.56$ & $52.54 \pm 0.39$ & $89.05 \pm 0.22$ & $92.21 \pm 0.02$ & $93.88 \pm 0.13$ & $94.07 \pm 0.14$ & 7.67 \\
\hline BSFDE & $14.56 \pm 0.60$ & $22.22 \pm 0.58$ & $40.93 \pm 0.93$ & $70.20 \pm 1.00$ & $90.47 \pm 0.80$ & $93.56+0.14$ & 27.95 \\
\hline BSLSEE & $11.70 \pm 1.64$ & $23.57 \pm 1.30$ & $53.17 \pm 0.77$ & $82.97 \pm 0.71$ & $88.20 \pm 0.40$ & $89.74 \pm 0.73$ & 24.36 \\
\hline BSLSBE & $25.93 \pm 0.32$ & $30.01 \pm 0.89$ & $65.40 \pm 1.19$ & $92.85 \pm 0.02$ & $94.67 \pm 0.17$ & $95.30 \pm 0.28$ & 15.14 \\
\hline BSLSEAE & $17.92 \pm 1.39$ & $33.94 \pm 0.81$ & $75.39+2.62$ & $92.64 \pm 0.12$ & $94.15+0.10$ & $94.62+0.08$ & 14.89 \\
\hline BSLSDE & $0.10 \pm 0.08$ & $4.63 \pm 0.95$ & $15.32 \pm 0.81$ & $33.49 \pm 0.94$ & $77.60 \pm 0.29$ & $90.65 \pm 0.11$ & 72.11 \\
\hline PAEE & $21.34 \pm 0.33$ & $31.42 \pm 0.64$ & $55.18 \pm 2.97$ & $85.52 \pm 0.27$ & $89.25 \pm 0.23$ & $90.42 \pm 0.35$ & 19.06 \\
\hline PABE & $14.06 \pm 0.79$ & $29.44 \pm 0.71$ & $70.08+0.20$ & $90.88 \pm 0.21$ & $92.79 \pm 0.12$ & $93.77 \pm 0.18$ & 17.71 \\
\hline PAEAE & $16.55 \pm 0.48$ & $28.51 \pm 0.02$ & $60.36 \pm 0.65$ & $90.06 \pm 0.29$ & $93.80 \pm 0.12$ & $94.49 \pm 0.08$ & 18.81 \\
\hline PADE & $6.63 \pm 0.42$ & $9.04 \pm 0.55$ & $14.16 \pm 0.36$ & $22.48+0.33$ & $45.30+0.41$ & $71.64+0.38$ & 140.41 \\
\hline EGb 761® & $4.15+0.38$ & $10.53 \pm 0.51$ & $28.32 \pm 0.43$ & $57.81 \pm 0.53$ & $90.47 \pm 0.62$ & $95.73 \pm 0.33$ & 49.79 \\
\hline
\end{tabular}

diseases and inflammation (Castro and Freeman, 2001).

According to Schnitzler et al. (2008), an aqueous extract of Pelargonium sidoides, in which coumarins were identified as major constituents, showed efficacy against herpes virus. Some other plant extracts and pure compounds isolated from natural sources have been tested and can be considered an important tool on herpes infection treatment (Khan et al., 2005).

None of the total ethanol extracts from $B$. segetum showed significant activity and the total ethanol extract from P. alopecuroides did not show any inhibitory activity against the Herpes simplex virus type 1 resistant to acyclovir (HSV-1-ACVr) either. However, this extract showed inhibitory activity against the herpes simplex virus type 2 resistant to acyclovir (HSV-2-ACVr) with a percentage of inhibition higher than $70 \%$ (Table 3 ). This may be due to the fact that this sample is a crude extract, with low content of active compounds. Based on that, the isolated coumarin from this extract was tested in the same conditions, showing a viral inhibitory rate almost two times bigger than the $P$. alopecuroides sample for HSV-2-ACVr. The coumarin was also active against HSV-1-ACVr (Table 3).
Herpes simplex virus (HSV) is widely spread around the world and represents an important cause of orolabial and genital ulceration. It is also responsible for neonatal morbidity, a co-factor for HIV transmission, particularly in developing countries (Patel and Rompalo, 2005 ), and it is also involved in several ocular diseases (Liesegang, 2001; Pepose et al., 2006). The two forms of Herpes simplex virus (HSV-1 e HSV-2) are morphologically similar and produce indistinguishable characteristics during the initial infection. However, HSV-1 and HSV-2 have an anatomical tropism and site-dependent incidence of reactivation, thus HSV-1 is more likely to reactivate producing orofacial infection while genital infection is frequently produced by HSV-2 (Pepose et al., 2006).

The results obtained in this test provide further evidence of the importance of $P$. alopecuroides on Herpes simplex treatment. According to Semple et al. $(1998,1999)$, Pterocaulon sphacelatum has antiviral activity suggesting that other species from Pterocaulon genus may also have antiviral activity. Coumarins have been related to HIV-1 protease inhibitory activity (Kirkiacharian et al., 2002). Our results

Table 3. Maximum Non-Toxic Concentration (MNTC), Viral Inhibitory Index (VII) and Percentage of Inhibition (PI) for Pterocaulon alopecuroides extract, Bidens segetum extracts and for the isolated coumarin against the Herpes simplex virus types 1 and 2 .

\begin{tabular}{|c|c|c|c|c|c|}
\hline \multirow{2}{*}{ Samples } & \multirow{2}{*}{$\frac{\mathrm{MNTC}}{\mu \mathrm{g} / \mathrm{mL}}$} & \multicolumn{2}{|c|}{ HSV-1-ACVr } & \multicolumn{2}{|c|}{ HSV-2-ACVr } \\
\hline & & VII & IP & VIR & IP \\
\hline Ethanol extract of $P$. alopecuroides & 200 & 0 & 0 & 0.65 & 77.6 \\
\hline Ethanol extract of $B$. segetum leave/stem & 200 & 0 & 0 & 0 & 0 \\
\hline Ethanol extract of $B$. segetum flowers & 200 & 0 & 0 & 0.15 & 29.2 \\
\hline $\begin{array}{l}\text { 7-(2',3'-dihidroxy-3'-methylbutyloxy)-6- } \\
\text { methoxycoumarin }\end{array}$ & 100 & 0.8 & 84.1 & 1.24 & 94.2 \\
\hline
\end{tabular}


suggest that 7-(2',3'-dihidroxy-3'-methylbutyloxy)6-methoxycoumarin can be responsible to the Herpes simplex virus inhibitory activity. Other assays will take place as a continuation of this research to try to find out the mechanism of action of 7-(2',3'-dihidroxy-3'methylbutyloxy)-6-methoxycoumarin against Herpes simplex virus.

\section{ACKNOWLEDGMENTS}

This study had the financial support of $\mathrm{CNPq}$, CAPES and FAPERJ.

\section{REFERENCES}

Abajo C, Boffill MA, Del-Campo J, Mendez MA, Gonzalez Y, Mitjans M, Vinardell MP 2004. In vitro study of the antioxidant and immunomodulatory activity of aqueous infusion of Bidens pilosa. J Ethnopharmacol 93: 319-323.

Agra MF, França PF, Barbosa-Filho JM 2007. Synopsis of the plants known as medicinal and poisonous in Northeast of Brazil. Rev Bras Farmacogn 17: 114140.

Agra MF, Silva KN, Basílio IJLD, França PF, Barbosa-Filho JM 2008. Survey of medicinal plants used in the region Northeast of Brazil. Rev Bras Farmacogn 18: 472-508.

Ballard R 1986. Bidens pilosa complex (Asteraceae) in North and Central America. Am J Bot 73: 1452-1465.

Beillerot A, Domínguez JCR, Kirsch G, Bagrel D 2008. Synthesis and protective effects of coumarin derivatives against oxidative stress induced by doxorubicin. Bioorg Med Chem Lett 18: 1102-1105.

Bohlmann F, Abraham WR, King RM, Robinson H 1981. Thiophene acetylenes and flavanols from Pterocaulon virgatum. Phytochemistry 20: 825-827.

Borges F, Roleira F, Milhazes N, Santana L, Uriarte E 2005. Simple coumarins and analogues in medicinal chemistry: occurrence, synthesis and biological activity. Curr Med Chem 12: 887-916.

Castro L, Freeman BA 2001. Reactive oxygen species in human health and disease. Nutrition 17: 163-165.

Da Costa FB, Terfloth L, Gasteiger J 2005. Sesquiterpene lactone-based classification of three Asteraceae tribes: a study based on self-organizing neural networks applied to chemosystematics. Phytochemistry 66: 345-353.

Debenedetti SL, De Kimpe N, Boeykens M, Coussio JD, Kesteleyn B 1997. Structural revision of four coumarins from Pterocaulon species. Phytochemistry 45: 1515-1517.

Debenedetti SL, Tehrani KA, Van Puyvelde L, De Kimpe N 1999. Isopurpurasol, a coumarin from Pterocaulon virgatum. Phytochemistry 51: 701-703.

Falcão DQ, Costa ER, Alviano DS, Alviano CS, Kuster RM, Menezes FS 2006. Atividade antioxidante e antimicrobiana de Calceolaria chelidonioides Humb. Bonpl. \& Kunth. Rev Bras Farmacogn 16: 73-76.

Farombi EO, Nwaokeafor IA 2005. Antioxidant mechanisms of kolaviron: studies on serum lipoprotein oxidation, metal chelation and oxidative membrane damage in rats. Clin Exp Pharmacol Physiol 32: 667-674.

Fylaktakidou KC, Hadjipavlou-Litina DJ, Litinas KE, Nicolaides DN 2004. Natural and synthetic coumarin derivatives with anti-inflammatory/antioxidant activities. Curr Pharm Des 10: 3813-3833.

Girennavar B, Jayaprakasha GK, Jadegoud Y, Gowdab GAN, Patila BS 2007. Radical scavenging and cytochrome P450 3A4 inhibitory activity of bergaptol and geranylcoumarin from grapefruit. Bioorg Med Chem
15: 3684-3691

Gonçalves JLS, Leitão SG, Romanos MTV, Miranda MMFS, Santos MGM, Romanos MTV, Wigg MD 2001. In vitro antiviral effect of flavonoid-rich extracts of Vitex polygama (Verbenaceae) against acyclovirresistant herpes simplex virus type 1 . Phytomedicine 8: 477-480.

Hoffmann B, Hölzl J 1989. Chalcone glucoside from Bidens pilosa. Phytochemistry 28: 247-249.

Hoult JR, Paya M 1996. Pharmacological and biochemical actions of simple coumarins: natural products with therapeutic potential. Gen Pharmacol 27: 713-22.

Khan MSY, Sharma P 1993. Synthesis of new $\alpha$-pyronoflavones and related products. Ind J Chem 32: 817-821.

Khan MTH, Ather A, Thompson KD, Gambari R 2005. Extracts and molecules from medicinal plants against herpes simplex viruses. Antiviral Res 67: 107-119.

Kirkiacharian S, Thuy DT, Sicsic S, Bakhchinian R, Kurkjian $\mathrm{R}$, Tonnaire T 2002. Structure-activity relationships of some 3-substituted-4-hydroxycoumarins as HIV-1 protease inhibitors. Farmaco 57: 703-708.

Kontogiorgis CA, Hadjipavlou-Litina DJ 2004. Synthesis and biological evaluation of novel coumarin derivatives with a 7-azomethine linkage. Bioorg Med Chem Lett 14: 611-614.

Kostova I 2005. Synthetic and natural coumarins as cytotoxic agents. Curr Med Chem Anticancer Agents 5: 29-46.

Lastra Valdes HA 2001. Bidens pilosa Linné. Rev Cuba Planta Med 1: 28-33.

Liesegang TJ 2001. Herpes simplex virus epidemiology and ocular importance. Cornea 20: 1-13.

Macleod JK, Rasmussen HB 1999. A hydroxy- $\beta$-caryophyllene from Pterocaulon serrulatum. Phytochemistry 50: 105-108.

Maes D, Debenedetti S, De Kimpe N 2006. New coumarins from Pterocaulon virgatum (L.) DC. Biochem Syst Ecol 34: 165-169.

Matheus ME, Berrondo LF, Vieitas EC, Menezes FS, Fernandes PD 2005. Evaluation of antinociceptive properties from Brillantaisia palisotti stems extracts. J Ethnopharmacol 102: 377-381.

Matheus ME, Fernandes SBO, Silveira CS, Rodrigues VP, Menezes FS, Fernandes PD 2006. Inhibitory effects of Euterpe oleracea Mart. on nitric oxide production and iNOS expression. J Ethnopharmacol 107: 291296.

Menezes FS, Falcão DQ, Mendonça-Filho RFW, Silveira CS, Renno MN, Rodrigues VP, Minto ABM, Moreira DL, Matheus ME, Fernandes PD, Kaplan MAC 2005. Chemical and pharmacological survey on Brazilian medicinal plants using ethnopharmacology information as a tool. Acta Horticulturae 675: 89-95.

Mongelli E, Pampuro S, Coussio J, Salomon H, Ciccia G 2000. Cytotoxic and DNA interaction activities of extracts from medicinal plants used in Argentina. $J$ Ethnopharmacol 71: 145-151.

Nunes XP, Mesquita RF, Silva DA, Lira DP, Costa VCO, Silva MVB, Xavier AL, Diniz MFFM, Agra MF 2008. Constituintes químicos, avaliação das atividades citotóxica e antioxidante de Mimosa paraibana Barneby (Mimosaceae). Rev Bras Farmacogn 18 (Supl): 718-723.

Oliveira FQ, Andrade-Neto V, Krettli AU, Brandão MGL 2004. New evidences of antimalarial activity of Bidens pilosa roots extract correlated with polyacetylene and flavonoids. J Ethnopharmacol 93: 39-42.

Patel R, Rompalo A 2005. Managing patients with genital herpes and their sexual partners. Infect Dis Clin North Am 19: 427-438.

Pepose J, Keadle T, Morrison L 2006. Ocular Herpes simplex: changing epidemiology, emerging disease patterns, and the potential of vaccine prevention and therapy. Am J Ophthalmol 141: 547-547.

Rabe R, Van Staden J 1997. Antibacterial activity of South African plants used for medicinal purposes. $J$ 
Ethnopharmacol 56: 81-87.

Reed LJ, Muench H 1938. A simple method of estimating fifty percents endpoints. Am J Hyg 27: 493-497.

Rice-Evans C, Miller NJ, Paganga G 1996. Structureantioxidant activity relationship of flavonoids and phenolic acids. Free Radic Biol Med 20: 933-956.

Riveiro ME, Shayo C, Monczor F, Fernández N, Baldi A, De Kimpe N, Rossi J, Debenedetti S, Davio C 2004. Induction of cell differentiation in human leukemia U-937 cells by 5-oxygenated-6,7methylenedioxycoumarins from Pterocaulon polystachyum. Cancer Lett 210: 179-188.

Schnitzler P, Schneider S, Stintzing FC, Carle R, Reichling J 2008. Efficacy of an aqueous Pelargonium sidoides extract against herpesvirus. Phytomedicine 15: 1108-1116.

Semple SJ, Reynolds GD, O'Leary MC, Flower RLP 1998. Screening of Australian medicinal plants for antiviral activity. J Ethnopharmacol 60: 163-172.

Semple SJ, Nobbs SF, Pyke SM, Reynolds GD, Flower RLP 1999. Antiviral flavonoid from Pterocaulon sphacelatum, an Australian aboriginal medicine. $J$ Ethnopharmacol 68: 283-288.

Silva CG, Herdeiro RS, Mathias CJ, Panek AD, Silveira CS, Rodrigues VP, Renno MN, Falcao DQ, Cerqueira DM, Minto ABM, Nogueira FLP, Quaresma CH, Silva JFM, Menezes FS, Eleutherio ECA 2005. Evaluation of antioxidant activity of Brazilian plants. Pharmacol Res 52: 229-233.

Stanczyk M, Gromadzinska J, Wasowicz W 2005. Roles of reactive oxygen species and selected antioxidants in regulation of cellular metabolism. Int J Occup Med Environ Health 18: 15-26.

Stein AC, Sortino M, Avancini C, Zacchino S, Von Poser $G$ 2005. Ethnoveterinary medicine in the search for antimicrobial agents: Antifungal activity of some species of Pterocaulon (Asteraceae). $J$ Ethnopharmacol 99: 211-214.

Torres R, Faini F, Modak B, Urbina F, Labbé C, Guerrero J 2006. Antioxidant activity of coumarins and flavonols from the resinous exudate of Haplopappus multifolius. Phytochemistry 67: 984-987.

Vera N, Bardon A, Catalan CAN, Gedris TE, Herz W 2001. New coumarins from Pterocaulon polystachyum. Planta Med 67: 674-677.

Vicentino ARR, Menezes FS 2007. Atividade antioxidante de tinturas vegetais, vendidas em farmácias com manipulação e indicadas para diversos tipos de doenças pela metodologia do DPPH. Rev Bras Farmacogn 17: 384-387.

Vilegas W, Boralle N, Cabrera A, Bernardi AC, Pozetti GL, Arantes SF 1995. Coumarins and a flavonoid from Pterocaulon alopecuroides. Phytochemistry 38: 1017-1019.

Von Kruedener S, Schneider W, Elstner EF 1996. Effects of extracts from Populus tremula L., Solidago virgaurea L. and Fraxinus excelsior L. on various myeloperoxidase systems. Arzneim-Forsch 46: 809814.

Wua CR, Huang MY, Lin YT, Ju HY, Ching H 2007. Antioxidant properties of Cortex fraxini and its simple coumarins. Food Chem 104: 1464-1471. 